\title{
Diffuse hyperintense brainstem lesions in neuroborreliosis
}

\begin{tabular}{|c|c|}
\hline Figure 1 & $\begin{array}{l}\text { Brain MRI at admission: Axial fluid- } \\
\text { attenuated inversion recovery } \\
\text { images show extensive diffuse } \\
\text { hyperintense lesions with mild } \\
\text { swelling in the diencephalon } \\
\text { and mesencephalon (A, B) and } \\
\text { focal cerebellar lesions (A) }\end{array}$ \\
\hline
\end{tabular}
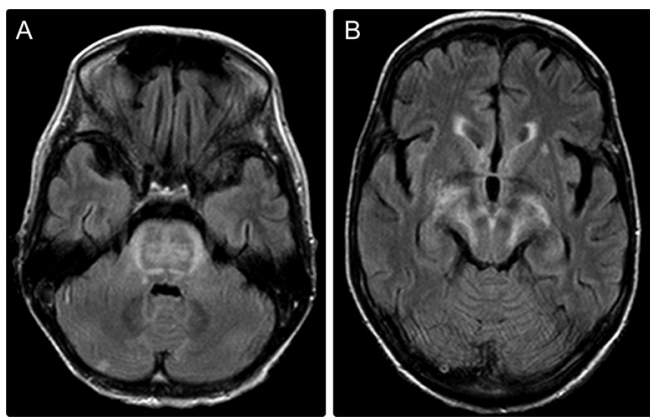

\begin{tabular}{|ll|}
\hline Figure 2 & Brain MRI at 6 months' follow-up: \\
& Almost complete resolution of \\
& abnormalities after 6 months (A, \\
& B), but certain low-density \\
& areas are noticeable (A)
\end{tabular}
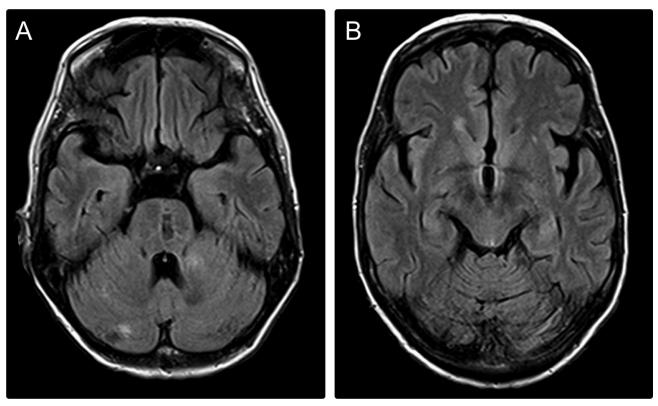

A 64-year-old woman presented with a 2-month history of neck pain, wasting, and fatigue followed by gait disturbance, dysarthria, and dysmetria. MRI showed profound hyperintensities in diencephalon, mesencephalon, and cerebellum correlating with symptoms (figure 1). Lymphoma, vasculitis, multiple sclerosis, and tuberculosis were excluded. Neuroborreliosis was diagnosed based on intrathecal immunoglobulin $\mathrm{G}$ synthesis (specific antibody index ${ }^{1}$ by indirect immunofluorescence 6.9, normal $<2$ ) along with abnormal CSF (113 cells $/ \mathrm{mm}^{3}$, protein $2.25 \mathrm{~g} / \mathrm{L}$, positive oligoclonal bands).

The specific antibody index is calculated as follows:

$$
\frac{\text { titer of } \lg G \text { in CSF }}{\text { titer of } \lg G \text { in serum }}: \frac{\text { total concentration of } \operatorname{lgG} \text { in } C S F}{\text { total concentration of } \lg G \text { in serum }}=\frac{1: 1024}{1: 2048}: \frac{636 \mathrm{mg} / \mathrm{L}}{8800 \mathrm{mg} / \mathrm{L}}
$$

Intravenous ceftriaxone led to nearly complete resolution of signs, symptoms, and MRI abnormalities (figure 2), demonstrating an exceptional case in contrast to usually unspecific MRI findings in neuroborreliosis. ${ }^{2}$

Adrian Haene, MD, Mathias Tröger, MD, Aarau, Switzerland

Disclosure: The authors report no disclosures.

Address correspondence and reprint requests to Dr. Adrian Haene, Department of Neurology, Cantonal Hospital Aarau, Tellstrasse, 5001 Aarau, Switzerland; adrian.haene@swissonline.ch

1. Blanc F, Jaulhac B, Fleury M, et al. Relevance of the antibody index to diagnose Lyme neuroborreliosis among seropositive patients. Neurology 2007;69:953-958.

2. Aalto A, Sjöwall J, Davidsson L, Forsberg P, Smedby Ö. Brain magnetic resonance imaging does not contribute to the diagnosis of chronic neuroborreliosis. Acta Radiol 2007;48:755-762. 


\section{Neurology}

\section{Diffuse hyperintense brainstem lesions in neuroborreliosis Adrian Haene and Mathias Tröger \\ Neurology 2009;73;326 \\ DOI 10.1212/WNL.0b013e3181af78cc}

This information is current as of July 27, 2009

\section{Updated Information \& Services}

References

Permissions \& Licensing

Reprints including high resolution figures, can be found at: http://n.neurology.org/content/73/4/326.full

This article cites 2 articles, 1 of which you can access for free at: http://n.neurology.org/content/73/4/326.full\#ref-list-1

Information about reproducing this article in parts (figures,tables) or in its entirety can be found online at: http://www.neurology.org/about/about_the_journal\#permissions

Information about ordering reprints can be found online: http://n.neurology.org/subscribers/advertise

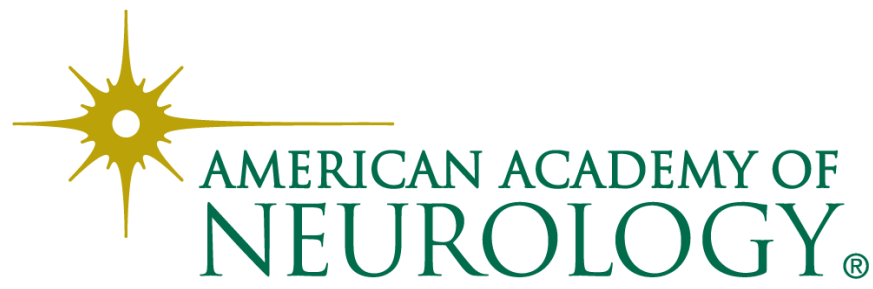

